\title{
Cellular Senescence and Its Relation with Telomere
}

\author{
Diego Julio Arenas-Aranda1, \\ Elena Hernández-Caballero ${ }^{2}$ and Fabio Salamanca-Gómez ${ }^{1}$ \\ ${ }^{1}$ Unit of Medical Research in Human Genetics, Medical National Center 21st Century, \\ Mexican Institute of Social Insurance, \\ ${ }^{2}$ Section of Posgrado's Studies and Investigation, High School of Medicine, \\ Technical National Institute. Mexico City, \\ Mexico
}

\section{Introduction}

For years it was thought that cells under culture conditions were immortal; however, from the publication of the works of Leonard Hayflick, this concept changed. Hayflick demonstrated that somatic cells under culture conditions had a limited capacity to proliferate; they stop dividing and enter into permanent arrest in the cell cycle, known as senescence. A particular characteristic of this state is that the cell maintains its viability and metabolic activity, and despite the presence of nutrients and mitogens, it does not divide (Ouellette et al., 2000). There are reports of cells that have been maintained in this state during several decades (Michaloglou et al., 2005). Regarding the origin of this process in mammalian cells, two different and apparently contradictory hypotheses have been proposed: senescence as a mechanism that suppresses tumor development, and senescence as the loss of the cells' regenerative capacity in vivo. In terms of the first hypothesis, senescence possesses a beneficial effect for the organism because it would avoid the development of cancer; otherwise, the second hypothesis would exert a harmful effect on organisms in that it would favor aging. Commentary will appear later on that both hypotheses joined together in the antagonist pleiotropic hypothesis (Williams, 1957; Campisi \& Adda di Fagagna, 2007; Campisi, 2011).

\section{Hayflick experiments}

It was 50 years ago that Hayflick first reported on the condition of mortality that cells maintain (Hayflick \& Moorhead, 1961), which the researcher himself cited in 1998 (Hayflick, 1998). To the present day, few have dared to enter into the study of Biogerontology. The generalized belief was that cells kept under culture conditions could replicate themselves indefinitely; if this were not possible, it would be due to lack of knowledge on the appropriate conditions for maintaining cells under culture (Hayflick, 2003). Carrel in 1921 stated that it was possible to keep chicken-heart fibroblasts indefinitely, maintaining these with embryonic tissue extract. However, as Hayflick noted, this experiment involved a great 
technical error because the extract with which the culture was nourished throughout 34 years was supplied with fresh cells throughout the entire time that the experiment lasted (Hayflick, 1998).

Hayflick identified three phases in his cellular proliferation experiments: phase I or that of primary culture, in which cells initiate their proliferation; phase II, that of rapid and continuous proliferation, and phase III, in which proliferation velocity diminishes and is finally detained (Hayflick \& Moorhead, 1961). Hayflick concludes that cells possess some type of counting mechanism because they stop dividing after a certain number of duplications, between 40 and 60 . This counting mechanism is conserved even after the cells are frozen and cultured anew (Hayflick \& Moorhead, 1961; Hayflick, 1965).

Some years later, thanks to the work of McClintock on chromosomal ends (McClintock, 1941), Olovnikov formulated his theory concerning the problem of replication and the solution to this. Suggesting that the inability of polymerase to replicate chromosomal ends totally was what could lead to cellular senescence, he proposed that the ends could function as a buffer, avoiding the loss of important sequences, but that in turn, this buffer function could also could be lost with successive replications (Olovnikov, 1996). Later, with the discovery of the telomeric repeats sequence of and telomerase by Blackburn, the study of telomeres and their participation in the senescence process began.

Currently, the existence is accepted of a limit of normal somatic cell replication, denominated the Hayflick limit. However, once the importance is established of telomerase as the enzyme that synthesizes telomeres (Greider \& Blackburn, 1985), it was discovered that this enzyme is found to be active in immortalized cell lines (Morin, 1989), tumor cells (Kim et al., 1994), stem cells (Chiu et al., 1996), and embryonic and germinal cell lines (Mantell \& Greider, 1994; Wright et al., 1996).

\section{The antagonistic pleiotropy hypothesis}

Antagonistic pleiotropy is a concept pertaining to Evolutionary Biology that proposes that some genes can have an impact on the physical state of the organism differentially throughout its lifetime (Williams, 1957; Tuminello \& Han, 2011). It is suggested that senescence evolved as an example of antagonistic pleiotropy; thus, its characteristics are beneficial in a reproductively active organism; later in this organism's lifespan, these characteristics become deteriorating. That is, senescence is the result of the random accumulation, whether passive or active, of harmful mutations (Kirkwood, 1977), reducing vigor and longevity, after the individual has passed reproductive age (Walker, 2011), although there is no definitive evidence that supports the negative effect of senescence in old persons.

Diverse processes have been found that are considered examples of antagonistic pleiotropy. Inflammation is a vital process to fight against infections and for cicatrization at all ages, but is also a process that can have negative effects if it becomes chronic in old age (Hornsby, 2010). On analyzing the influence of TP53 polymorphisms on cancer with respect to age, Cherdyntseva et al. (2010) found a relationship between the presence of polymorphisms in both genes and the increase of the risk of lung cancer in young, but not in older, smokers, 
while the combination of wild-type alleles increased the risk of lung cancer in individuals aged $>60$ years. The researchers concluded that p53 protects the organism against cancer at the beginning of life, but that it promotes the aging phenotype in older persons, including the appearance of cancer at the end of life. Another recent study suggests that allele $\varepsilon 4$ carriers enjoy a beneficial cognitive effect in youth, and that later at an advanced age present cognitive diminution, which could increase the risk of presenting Alzheimer disease, although it could be that this allele is not pleiotropically antagonistic, but rather that it interacts with other risk factors for Alzheimer disease (Tuminello \& Han, 2011). Feltes et al. (2011) suggest that aging and age-associated diseases could be the result of a program of development that is activated from the embryo stage, that persists throughout life, and that is regulated by the interaction of protein networks that connect environmental with molecular signals. The protein networks of the immune system, the epigenetic network, and aerobic metabolism are subject to great selection pressure during embryogenesis. However, this pressure becomes more relaxed in the adult, which allows the initiation of aging-associated diseases.

\section{Somatic cells and senescence}

After gametes are fused during the fertilization process, that primordial cell denominated the zygote begins a long journey in the formation of the individual. However, this journey begins with an accelerated expansion in the number of cells, which later decelerates. Once the organism has been formed, it will utilize cellular replication during its entire lifetime to grow, regenerate its tissues, cure wounds, or during the immune response.

Somatic cells possess a limited number of possible cell divisions, after which these become refractory to mitogeneic stimuli and enter into replicative senescence. In 2001, Sin et al. cite that aging at the cellular level is the result of cell function alterations, such as the response to DNA structural changes that is reflected in the expression of genes. A senescent cell remains arrested at cell cycle stage G1, and although it does not divide again, it remains metabolically active for a long time. The accumulation of mutations and damage to the DNA, together with inefficient repair mechanisms, become critical with each cell division and cause genetic heterogeneity in aging cells (De, 2011). There are somatic cells that possess the capacity to renew themselves, such as epithelial and blood cells, while there are cells that once differentiated, do not divide again, such as neurons. The equilibrium in death maintains homeostasis in the individual; thus, excessive death can lead to tissue degeneration and the inability to die can lead to hyperplasia and finally, cancer. The accumulated errors in a senescent cell's DNA can alter this balance and cause diverse diseases (Hotchkiss et al., 2009).

\section{Senescent phenotype}

To date, there is no senescence marker that is totally specific for this stage because not all senescent cells express the same markers. These cells can exhibit diverse changes that in their entirety can aid us in defining the senescent phenotype (Rodier \& Campisi, 2011).

Change in cell volume is one of the most evident characteristics of a senescent cell, because cells may be observed that range from $1,000 \mu \mathrm{m}^{2}$ in an early passage of human fetal 
fibroblasts up to $9,000 \mu \mathrm{m}^{2}$ in terminal passages of the culture. Size increase has been correlated with changes in cytoskeletal organization (Wang \& Gundersen, 1984), which leads to modification in cell shape. For example, fibroblasts lose their typical tapered form to acquire a flat appearance (Greenberg et al., 1977), apparently due to changes in the expression of diverse cytoskeletal proteins. Nishio et al. (2001) found that senescent fibroblasts contain three times the amount of the cytoskeletal protein vimentin as embryonic fibroblasts. Vimentin presents as dense filament bundles that are parallel to the longest cellbody axis in senescent cells, while in young cells vimentin formation is observed as a network of short and thin filaments. The authors also demonstrated that young fibroblasts acquire a senescent phenotype once they are transfected with a vector that over expresses the vimentin gene, while actin levels diminish in senescent fibroblasts (Nishio \& Inoue, 2005). This diminution causes rigidity in old donor cells and increases in the kinesis of cell reorganization (Zahn et al., 2011). On the other hand, cellular adhesion of aging fibroblasts increases. It was found recently that the senescence of vascular epithelial cells induces an increase in cell adhesion proteins, which in turn increases the adhesion of monocytes to endothelial cells through their binding with Intracellular adhesion molecule 1 (ICAM1), contributing to the appearance of atherosclerosis (Yanaka et al., 2011).

Another characteristic of cellular senescence is change in diverse organelles; a very common occurrence comprises the increase in lysosome number and size. In lysosomes, granules of lipofuscin, the so-called aging pigment, accumulate (Brunk \& Terman, 2002; Gutteridge, 1984). This material cannot be degraded by the cell's proteolytic machinery, is highly toxic, and inhibits the degradation of oxidized proteins (Bader et al., 2007; Höhn et al., 2011). Another lysosome-linked senescence biomarker is $\beta$-galactosidase, which is derived from the $\beta$-D-galactosidase and whose activity increases in senescent cells. In non-senescent cells, lysosomes possess a pH4-optimal function, while when the cell ages, the lysosomal compartment expands and $\beta$-galactosidase increases; thus, it is possible to detect a suboptimal $\mathrm{pH}$ of 6 , a change known as senescence-associated $\beta$-galactosidase activity (Dimri et al., 1995; Lee et al., 2006). Senescence is also implicated in the deterioration of mitochondrial function and in the appearance of mutations in mitochondrial DNA, due to the lack of a repair system (Percy et al., 2008), and it is considered that aberrant production of Reactive oxygen species (ROS) can increase the mitochondrial mass (Hwang et al., 2009) and on the other hand accelerate telomere shortening and contribute to cellular aging (Liu et al., 2002) due to damage to the DNA. With respect to the nucleus, the increase in chromatin condensation is the most evident nuclear change. Regions are formed that are known as Senescence-associated heterochromatin foci (SAHF); these DNA regions are associated with heterochromatin proteins such as HP1 and H3K9m (Narita et al., 2003). SAHF are also evident in cells that become senescent because of oncogenic stress with H-Ras (Kosar et al., 2011).

Changes in senescent cells are also reflected in their functions; for example, fibroblasts under culture conditions adopt a matrix-degrading phenotype, while adrenal cortex epithelial cells produce an altered steroid-hormone profile (Campisi, 2000). Due to the increase in the secretion of pro-inflammatory proteins such as interleukins and chemokines, it is said that senescent cells are found in a pro-inflammatory state (Freund et al., 2010), which in an aging organism can favor tissue deterioration. 


\subsection{Changes in gene expression, growth arrest, and apoptosis resistance}

Cell cycle arrest-associated replicative senescence is related with telomere shortening and, as previously noted, is a response for suppressing tumor formation and that can have aging of the organism as a side effect (Harley et al., 1990; Campisi, 2011). The cell population gradually stops dividing. (Thomas et al., 1997). Cell growth inhibition can be the result of cellular quiescence, whether due to lack of growth or nutrient factors or to other in- and extrinsic factors. This leads to the cell's exhibiting a low metabolic rate, low protein synthesis and cell functions, and the absence of growth (Blagosklonny, 2011). The senescent cell is defined by the permanent lack of replicative potential despite receiving a mitogenic stimulus (Rodier \& Campisi, 2011). The cells remain arrested in G1, although on some occasions can be stopped in G2 (Harley et al., 1990). The central signaling pathways for senescence are represented by the p16-pRb Retinoblastoma $(\mathrm{Rb})$ protein and the p53 tumor suppressor (Lowe \& Sherr, 2003). The p14-p53-p21 pathway is partially telomere-dependent, while the p16-pRb pathway is independent of the presence of dysfunctional telomeres (Campisi \& d'Adda di Fagagna, 2007). The product of $p 53$ gene accumulates in response to cellular stress, which activates a specific gene target program to restrict the growth of abnormal or damaged cells; the result can be apoptosis, transitory cell cycle arrest, or permanent arrest (Beausejour et al., 2003). Thus, the product of $p 53$ gene possesses anti-cancerous as well as pro-aging effects depending upon the context of the individual's age (Campisi, 2005). Among p53 target genes are found the Cyclindependent kinase (CDK) inhibitor p21, the pro-apoptotic genes BAX and APAF1, and the E3 ubiquitin ligase, MDM2 (Vousden \& Lu, 2002). p53 expression is controlled by p19 (Arf). On the other hand, $\mathrm{Rb}$ expression is controlled by p16Ink4a, whose protein levels increase in senescent cells. p16Ink4a maintains pRb in a hypophosphorylated state, which inhibits cell proliferation and induces growth arrest through the pRB effect on E2F; this is necessary to activate the genes implicated in cell cycle progression (Campisi \& d'Adda di Fagagna, 2007). Both signaling pathways interact and are reciprocally regulated. However, each can interrupt the cell cycle independently.

As Blagosklonny (2011) cites, cell arrest is only one part of the senescence equation, because senescent cells also become resistant to apoptosis. There are mechanisms of defense that augment apoptosis resistance, increasing anti-apoptotic signaling and avoiding the death of damaged cells. The increase of apoptosis resistance is a cell safety mechanism, because if cells have an acute stress due to some damage, they possess the capacity of recovering their homeostasis. However, in aging, when stress becomes persistent apoptosis resistance can cause the survival of undesired cells (Hampel et al., 2004; Salminen et al., 2011). It has been observed that the equilibrium between apoptotic and pro-apoptotic proteins changes with age. Bcl-2 and Bcl-xL protein levels are higher in aging than in young fibroblasts, while proapoptotic Bax levels are higher in young cells (Rochette \& Brash, 2008). Apoptosis markers such as FasL and cytochrome C decrease in serum and, on the other hand, levels of soluble Fas (an apoptosis inhibitor) increase (Kavathia et al., 2009). Salminen et al. (2011) suggest that apoptosis resistance can affect the host's defenses in age-related fashion, a situation that meets promoted by the chronic inflammation that senescent cells develop.

\section{Senescence markers}

There are some molecular senescence markers that are characteristic of damage to DNA, including the nuclear foci of phosphorylated histones H2AX and DNA damage response 
factors such as 53BP1, MDC1, and NBS1 (d'Adda di Fagagna, 2008), which explains why culture shock can trigger senescence without the participation of telomeres. p16 is used for identification of senescent cells due to that it is overexpressed in the majority of these cells (Krishnamurthy et al., 2004). Although it has been demonstrated that in Caenorhabditis elegans alterations in microRNA's (miRNAs) expression are associated with aging, the role that these could play in mammals remains unknown. In C. elegans, lin-4 over expression leads to an extension in its life span, while loss of lin- 4 reduces the life span (Boehm \& Slack, 2005). Lin- 4 acts on the lin-14 messenger, affecting not only the life span, but also the insulin signaling pathway (Hung et al., 2010).

\section{Causes of cellular senescence}

In stem cells, it has been observed that premature differentiation and senescence are alternatives to DNA damage repair that can exert a beneficial effect on restricting the accumulation of defective stem cells. However, sensitivity to DNA damage and p53-related apoptosis induction differ widely among stem cells (Blanpain et al., 2011). The stem cells of melanocytes, for example, undergo premature differentiation, which reduces the stem cell pool and causes graying of the hair (Inomata et al., 2009). On the other hand, loss of TP63 (a member of the p53 family) in dermal precursors leads to skin ulceration and cicatrization defects due to genomic instability and the induction of senescence (Su et al., 2009).

Recently, a chromatin remodeling factor was found to be implicated in replicative senescence, the Jun 2 dimerization protein (JDP2), which binds to histones and inhibits the binding of Polycomb repressor complexes (PRC1 and PRC2) to p16 gene promotor (Huang et al., 2011).

\subsection{Telomere-induced senescense}

The loss of proliferative potential can be a genetically programmed process. The telomereassociated aging theory suggests that progressive telomere sequence loss triggers chronic p53 activation, which consequently leads the cell to halt its proliferation (Lee et al., 1998). Telomere shortening is a stochastic event; thus, telomere length varies greatly among individuals (Halaschek-Wiener et al., 2008).

Dysfunctional telomeres trigger the response to DNA damage, which includes activation of ATM, 53BP1, Mdc1, Chk2, and H2AX, in addition to over expression of cell cycle inhibitors p21Cip1/Waf1 and p16INK4a and under expression of different cell cycle proteins (Herbig et al., 2004).

\subsection{Senescence induced by non-telomeric chromatin alterations}

Non-genotoxic stress can cause perturbations in chromatin, that is, epigenetic changes that can alter the genetic schema of the cell. It has been demonstrated that global genome methylation diminishes with age. However, it has also been observed that the promoters of certain genes can be hypermethylated, thus silenced. Histones themselves undergo modifications during aging, whether because of methylation or hypoacetylation; all of these chromatin regions in senescent cells are observed as transcriptionally inactive domains 
(SAHF) (Funayama, 2007). One characteristic of the senescence program is observed in cultured fibroblasts in chromatin reorganization through $\mathrm{H} 3$ methylation in the Lys9 residue and by protein recruitment in the heterochromatin. Some agents that interact with DNA, such as doxorubicin, cisplatin, taxol, vincristine, cytarabine, and etoposide, can produce the senescent phenotype in tumor cells (Chang et al., 1999).

It has been suggested that the condensation of genes implicated in proliferation through SAHF formation can contribute directly to senescence-associated silencing. However, it was recently suggested that SAHF are the result of persistent damage to the DNA and that it is condensation of the genes that promote proliferation, to a greater extent than large-scale SAHF, which detains senescence-associated proliferation (Rai \& Adams, 2011).

\subsection{Senescence induced by stress and other factors}

Cellular senescence can additionally be induced prior to telomere shortening, which is also known as premature senescence or stress-induced premature senescence. One example are fibroblasts under culture, which are exposed to stress by abnormal concentrations of nutrients and growth factors, in addition to the absence of neighbor cells and extracellular matrix, which can lead to the senescent phenotype (Sherr \& DePinho, 2000). It also results from exposure to mutagens, such as ionizing radiation, ROS, chemotherapeutic agents, or bacterial toxins (Campisi \& d'Adda di Fagagna, 2007); thus, the molecular mechanisms of induction are nearly identical to replicative senescence, that is, it is mediated by ATM-p53p21. Another type is oncogene-induced senescence (Vavrova \& Rezacova, 2011). However, it has been observed that moderate stress leads to telomere shortening and that the main cause of shortening is due to the presence of damaged bases, which interferes with the replication fork in telomeres, increasing the extension of the non-replicated ends (von Zglinicki, 2002; Duan et al., 2005). Non-genotoxic stress induces senescence by means of a telomereindependent mechanism, which involves p16-pRB pathway activation by p16 INK4a over regulation (Ben-Porath \& Weinberg, 2005).

Matos et al. (2011) recently analyzed the role of copper in inducing senescence in WI-38 fibroblasts and found that on exposing these to subcytotoxic copper sulfate concentrations, the fibroblasts exhibited the appearance of the senescent phenotype and an increase in senescence-associated genes such as $p 21$, apoJ, fibronectin, TGF $\beta 1$, IGFBP3, and Hemo oxigenase-1 (HO-1). These results are interesting because of the participation that copper can have in the establishment and progression of diseases such as Alzheimer and that of Wilson. On the other hand, it is possible that oxidative stress produces telomere shortening, therefore senescence, as confirmed by Brandl et al. (2011), because on exposing articular chondrocytes to oxidative stress with a sublethal dose of $\mathrm{H}_{2} \mathrm{O}_{2}$, the authors observed accelerated telomere exhaustion with over regulation of p21 expression and sub expression of SIRT1 and XRCC5, once the cells had acquired the senescent phenotype. Cellular senescence also can be induced by stress in the cultured cells, such as continuous mitogenic stimulation (Serrano \& Blasco, 2001). Sustained exposure of melanocytes to an aberrant mitotic stimulus causes senescence after an initial proliferative burst, such as that observed by Michaloglou et al. (2005) suggesting that oncogene-induced senescence represents a factor of protection against cancer. 


\section{The mammalian telomere}

Telomeres are restricted to chromosomal ends and present in eukaryotes as diverse protozoans, fungi, flagellates, plants, and animals. The greater part of telomere DNA is double-stranded; however, the terminal $3^{\prime}$ end is single-stranded. Each telomere is composed of a great region of short repeats rich in $\mathrm{G}$. The sequence comprising a telomere varies in length and complexity depending on the organism (Greider, 1996). In the case of humans and other mammals, the sequence is TTAGGG, while organisms such as yeasts possess irregular repeat sequences in which a $\mathrm{T}$ is followed by one, two, or three $\mathrm{Gs}_{\mathrm{s}}\left(\mathrm{TG}_{1-3}\right)$, while other organisms lack $\mathrm{A}$ in their repeats, as occurs in the ciliate Tetrahymena, which presents the TTGGGG sequence, and the Paramecium, which is distinguished by the TTGGGG and TTTGGG alteration.

Telomere DNA consists of two regions: one is double-stranded, and the other is singlestranded at its terminal end. The G-rich chain is that which projects further than the C-rich chain in the 3' direction. This salient is essential for telomere formation, due to that linear chromosomes need to protect their ends from degradation. The $3^{\prime}-\mathrm{OH}$ salient invades double-stranded telomere repeats, forming a loop-like structure called the T-loop (Telomere loop), in such a way that the salient remains hidden in the double chain (Griffith et al., 1999). The T-loop avoids that the ends are considered as DNA breaks and preserves genome integrity. The exact structure of the T-loop's base is unknown, but there is a short, doublestranded DNA segment that forms a D-loop (Displaced loop) of TTAGGG repeats, which is displaced by the invasion of the 3' salient (De Lange, 2002). The D-loop region can include Holliday-type binding (the intermediate state in homolog recombination) or a quadruple $G$ fold (Neidle \& Parkinson, 2003). The 3' salient, which in humans is between 35 and 600 nucleotides long, is the result of the impossibility of replicating the last fragment of Okasaki and of post-replicative processing events (Stewart et al., 2003).

\section{The shelterin}

Maintenance of telomeric structure and regulation of its functions are supplied by diverse proteins that stabilize it and that permit the cell to distinguish between a natural chromosomal end and a DNA break. Shelterin or Telosome is a six-protein complex whose function is to form and maintain the T-loop. TRF1 and TRF2 are the main shelterin proteins. TRF1 modules telomere length, while TRF2 stabilizes T-loop structure (Xin et al., 2008). Other proteins have been described that, in addition to associating with the telomere, possess other cellular functions, such as XRCC5, which participates in double-stranded DNA damage repair (Thacker \& Zdzienicka, 2004). SIRT1 is a negative regulator of p53 and that which avoids growth arrest, senescence, and apoptosis (Guarente, 1999). Doublestranded telomere DNA is wrapped in protein complexes that specifically bind to doublestranded proteins and that participate in the regulation of their length, while the 3 ' salient is wrapped in one or more single-stranded binding proteins that protect it (McEachern et al., 2000). The TRF protein family has a similar architecture, defined by two characteristic sequences: both have a DNA-binding motif in their helix-turn-helix carboxyl-terminus (highly related with the Myb domain of $\mathrm{cMyb}$ ), and both possess a centrally localized sequence motif known as the TRF homolog domain (TRFH), unique for this protein family, which allows it to form homodimers (Fairall et al., 2001). However, the TRFH domain does 
not form heterodimers, which leads to the presence of two protein complexes on the telomeres: one formed through TRF1, and the other by means of a paralog, TRF2 (Karlseder, 2003). TRF1 forms homodimers in order to bind stably to the DNA thanks to its Myb domain and, by means of T-loop formation, its binding with Rap1 at telomere repeats induces superficial double-strand folding, which indicates that it participates in loop formation (Bianchi et al., 1999). In cis, TRF1 acts in as a negative telomere length regulator. Its over expression produces telomere shortening and a dominant negative allele produces inappropriate lengthening in such a way that the amount of protein affects telomere size (Smogorzewska \& de Lange, 2002). TRF1 can control telomerase access through its interaction with proteins TIN2, PTOP/PIP1, and POT1 and regulates their activity on interacting with PINX1 (Zhou et al., 2001). It also binds to TANK1 and 2 (Smith et al., 1998). Elimination of TRF1 produces telomere lengthening, but the extension stabilizes eventually due to that now the TIN2/TINT1 complex associates with TRF2, blocking access to telomerase (Houghtaling et al., 2004).

On the other hand, the complex formed by TRF2 is particularly important for protecting single-strand of the degradation and DNA repair processes (van Steensel et al., 1998; Smogorzewska \& De Lange, 2004). TRF2 couples in the binding between double- and singlestranded repeats to facilitate T-loop formation, thus protecting its ends. In this manner, it is responsible for linear telomeric folding for T-loop formation (Griffith et al., 1999) and is found in >100 copies per chromosome (de Lange, 2002); additionally, given that it is the stabilizer of this structure, a lesser amount of TRF2 leads to T-loop opening, an event that can lead to senescence (Karlseder, 2003). Additionally, loss of TRF2 activates the AtaxiaTelangiectasia protein (ATM) kinase pathway, because while this is present it impedes autophosphorylation. ATM activation leads to p53 over regulation and G1/S arrest by means of p21 (Karlseder et al., 1999). When this is displaced from the telomere employing a dominant negative allele, the cell loses its ability to recognize the difference between a natural DNA end and a broken end. On the other hand, its over expression accelerates telomere shortening, which can be the result of the increase in the activity of a nuclease, whose activity is mediated by TRF2 (van Steelsen et al., 1998); Karlseder et al. (2002) suggest that an increase in TRF2 can protect critically short telomeres, delaying induction of cellular senescence even when the telomeres have been reduced. It can protect the single chain indirectly on recruiting Pot1.

It can bind to proteins such as Rap1 and to others involved in DNA damage repair responses, such as the MRE11/RAD50/NBS1 complex, Ku86, and ERCC1/XPF. Among its activities in blocking DNA repair is found that of avoiding that the T-loop insertion site is treated as a Holliday structure. On the other hand, inhibiting the binding of Nonhomologous end-joining (NHEJ) and homologous recombination in telomeres and probably in non-telomeric breaks allows determination of which repair pathway the cell should use (Wright \& Shay, 2005). On the other hand, TRF2 facilitates the degradation of telomeric DNA on interacting with the WRN exonuclease, whose loss-of-function is implicated in premature cellular senescence, increasing the frequency of cancer and genomic instability (Machwe et al., 2004).

There are diverse proteins that bind indirectly with telomeres; TIN2 has emerged as an important component of the telomere complex. It interacts with the telomere through the 
TRFH domain of TRF1, negatively regulating telomere length. A truncated form of TIN2 produces abnormal telomerase-independent telomere lengthening; therefore, it is a TRF1function mediator on potentiating the pairing of telomere repeats in a TRF1-dependent manner; in addition, it can lead to the telomerase-inhibiting telomere (Kanoh \& Ishikawa, 2003). In addition to this telomere-size regulator function, another mutant form generates DNA damage response and senescence (Kim et al., 2004). Through this protein, TRF1 and TRF2 can interact, while TIN2 can stabilize TRF2-complex binding to the telomere on acting as a liaison between this and TRF1. On the other hand, thanks to its third domain, it binds to PIP1/PTOP/TINT1, which in turn serves to recruit POT1 (Liu et al., 2004; Ye \& de Lang, 2004). On controlling the Poly (ADP-ribose) polymerase (PARP) activity of tankirase 1, TIN2 protects TRF1 on its removal from the telomere (Ye \& de Lang, 2004).

Tankirase 1 interacts with the TRF1. It is a PARP telomere that adds poly ADP-ribose to TRF1, diminishing its affinity for telomeric DNA (Smith \& de Lange, 2000). More than diminishing TRF1 affinity for telomere repeats, what TANK1 does on separating TRF1 from the DNA is to expose its myb domain, which is recognized and marked by ubiquitin, leading to degradation of the protein by the proteosome. If this were performed otherwise, TRF1 would bind again to the telomere and its separation would permit the telomerase to gain access to and extend it (Chang et al., 2003). TIN2 is what stabilizes TANK1 binding to the TRF1 complex, and although TANK1 is the lesser abundant of these two proteins, it is necessary for controlled dismantling of the telomere complex during $\mathrm{S}$ phase (Ye \& de Lange, 2004).

TANK 2, recently identified as a Golgi-associated protein, shares $80 \%$ identity in the aminoacid sequence with TANK1, in addition to similar distribution; however, when this is over expressed, it induces rapid cell death with necrotic characteristics (Kaminker et al., 2001). In addition and similar to TANK1, it is a PARP modifier of TRF1 and possibly possesses little effect on telomerase activity (d'Adda di Fagagna et al., 2004).

There are a variety of other proteins that bind to telomeres, such as $\mathrm{Ku}$, Rap1, PIP1/PTOP/TINT1, WRN, PINX1 (Stellwagen et al., 2003; Espejel et al., 2002; Kanoh \& Ishikawa, 2003; Köning \& Rhodes, 1997; Lei et al., 2000; Ye \& de Lange, 2004; Crabbe et al., 2004), and ATM. On the other hand, repair-machinery proteins such as the Mre11/Rad50/ /Nsb1 complex (the MRN complex), which participates in double-stranded DNA repair, can play a role in telomere maintenance, although it does not directly bind with it but rather interacts through TRF2 and possibly participates in T-loop formation (Saldanha et al., 2003). Among these single-stranded binding proteins is found POT1; this binds to a telomeric salient with exceptionally high specificity. It adopts an oligosaccharide-oligonucleotide (OB) joining fold with two forks that overhang to form a clamp for binding to DNA (Lei et al., 2003). When the PTO1 binding domain is mutated, there is no telomeric end fusion, but rather an increase in telomere extension by the telomerase; thus, one of its functions is to block the access of this enzyme to the DNA. TRF1 interacts with POT1; thus, it is the length control terminal transductor for TRF1. The more TRF1, more POT1, which leads to an increase in telomerase inhibition (Mattern et al., 2004). POT1 is necessary to maintain structure in telomere salients, protecting the cell against apoptosis, avoiding chromosomal instability and senescence, and interacting with TRF2 at the T-loop formation point, with which it cooperates for maintaining telomere integrity (Yan et al., 2005). 
Recently, it was discovered that Rap1 is an important factor for avoiding telomere recombination and fragility (Martínez \& Blasco, 2011).

\section{The telomerase}

Telomerase is a Ribonucleoprotein (RNP) composed of two units: the catalytic subunit, TERT, and a RNA template, TERC. TERT is a member of the family of reverse transcriptases related with non-LTR retrotransposons and group II introns. Its reverse transcriptase domain is found at the middle of the carboxyl-terminus and it supplies the active site for catalysis (Cech, 2004). TERC, also called TR, is highly expressed in all tissues, it not being important whether they possess telomerase activity or not, and it contains a short sequence that acts as a template from which DNA repeats are copied (Cong et al., 2002). Telomerase carries its own template and is restricted to copying solely a small segment of its RNA. Thus, implicit in telomerase polymerization activity is its ability to specify the template region and its limits, and also a mechanism for maintaining itself as a stable RNP while carrying out synthesis, because it allows the template to move through the active site during the synthesis process of a repeat, to later translocate itself and initiate the synthesis of another repeat. (O’Reilly et al., 1999; Cech, 2004).

When the telomere catalytic subunit in mouse mutates, the first generation that lacks telomerase activity is phenotypically normal, with long telomeres. After four to six generations, its telomeres become very short, and the mice suffer from infertility, proliferation defects, and the risk of apoptosis in organs that undergo constant turnover, which diminishes their life span, while a TERC gene mutation causes Dyskeratosis congenita (DKC), a disease in which, among other characteristics, the telomeres are abnormally short (Blasco, 2005).

There are accessory factors that aid the telomerase in acting on the telomere, such as dyskerin and TP1. Dyskerin is important for ribosomal processing because it binds to many small nucleolar RNA, and it is implicit in TERC and even TERT processing or stability because its small nucleolar RNP domain reached maturation in the nucleolus and later binds to the dyskerin (Cech, 2004). TP1 can form one or more structures that mediate interactions with other telomerase- or telomere-binding proteins such as TRF. The TP1 pattern of expression is not restricted to tissues and cell lines that express telomerase activity; therefore, it is not an essential subunit (Harrington et al., 1997).

Chai et al. (2006) found that it is possible that telomerase preferentially extends the leader chain of 20-30 nucleotides per replication round in order to produce a salient similar to that of the delayed chain, because the leader-chain salient is smaller, which otherwise would affect the conformation of telomere structure.

Telomerase-to-telomere access regulation is carried out by telomere-associated proteins, for example, TRF1 and TRF2; on forming the T-loop, these inhibit telomerase binding, while POT1 binding to the salient does not permit coupling of the enzyme so that this would extend it.

Mutations in telomerase components produce premature dysfunctions in adult stem cells and reduce longevity (Mitchell et al., 1999). 


\section{Telomere position effect (TPE)}

At present, it is accepted that telomere clipping can affect gene expression in subtelomeric regions, which can lead to modification of the Biology of the cell prior to initiation of replicative senescence (Baur et al., 2001).

The Position variegation effect (PVE) refers to inactivation of a gene, which occurs when it is removed from its normal context by means of a rearrangement or by transgene insertion. The best known example of this is the result of the expression of the euchromatic white gene in Drosophila, which is responsible for the red color of the eye. Provoked by a rearrangement in chromosome $\mathrm{X}$ that causes its relocation near the heterochromatin region, it eliminates function in some cells, which produces mottled pigmentation. The explanation for silencing of the white gene in some cells and not in others is that condensed and inactive conformation of pericentric heterochromatin is dispersed on the rearrangement break and randomly inactivates nearby genes (Henikoff, 1990). This chromosomal position effect affects up to a distance of approximately $1 \mathrm{Mb}$ and reflects a genetic inactivation gradient that is inversely correlated with distance (Wakimoto, 1998). The PVE phenomenon suggests that heterochromatin forms a transcriptionally repressor environment within which the presence of heterochromatically active resident genes is somewhat paradoxical, because these genes exhibit reciprocal heterochromatic PVE, that is, a heterochromatic gene will undergo variation if it is translocated to an euchromatic ambit. From this arises the suggestion that these genes have developed transcriptional dependence in factors that normally silence the expression of other genes (Schulze et al., 2005). Among proteins known to possess an important function in gene silencing in Drosophila is found HP1, which is a protein associated with pericentric heterochromatin. It has unequal distribution through the genome and is principally associated with the fourth chromosome. Specifically, it exerts an impact on structural organization and does not only cover the DNA or serves to direct all repetitive DNA sequences toward the repressive structure (Cryderman et al., 1999).

In the case of Saccharomyces cerevisiae, the heterochromatin is not cytologically visible; however, it presents position effects in three places: the telomeres; the rDNA locus, and the silent "mating-type" loci (HML and HMR). When a gene is found in one of these sites, its transcription is repressed. As in PVE, silencing depends on gene localization and not on its sequence (Chen \& Widom, 2004). Several proteins are involved in the repressive chromatin, including $\mathrm{H} 3$ and $\mathrm{H} 4$ histones, their acetylases and associated deacetylases, the molecular regulators Sir1-Sir4, and the Origin recognition complex (ORC) (Pryde \& Louis, 1999). The four Sir proteins are necessary for transcriptional silencing in HML and HMR, while only Sir2p, Sir3p, and Sir4p are required for telomere silencing and only Sir2p is required for rDNA silencing (Chen \& Widom, 2004). TPE was described for the first time in 1990 through generation of a terminal deletion that caused the URA3 gene (the gene necessary for uracil synthesis) to be localized $6 \mathrm{~kb}$ from a telomere. This new gene position provoked its transcriptional repression, which was lost when this was localized $20 \mathrm{~kb}$ from the telomere (Gottschling et al., 1990).

It was in 1992 that Wright and Shay set forth the possibility that TPE exists in humans. However, the first experimental proposal to identify TPE in humans, carried out by Bayne et al. (1994), did not yield positive results because changes were not found in the hygromycinresistant gene on generating deletions in the long arm of chromosome X. Again, this time in 
1996, Sprung et al. (1996) sought to study the telomere-length effect on HSV-tk promotor expression, utilizing the KB319 cell line (SV40-transformed fibroblasts); the authors integrated a plasmid with the neo-gene at the end of chromosome 13 and found no effect on neo-gene expression when telomere length ranged from $25-0.5 \mathrm{~kb}$; this leads them to suggest that chromatin structural differences conferred by telomere length do not affect the expression of nearby genes. A $130-\mathrm{kb}$ microdeletion in the end of chromosome 22q in cells from a child with mental retardation; the broken end had been repaired by telomere addition, and consequently a unique DNA region that was normally localized at a distance of $>100 \mathrm{~kb}$ from the telomere was now adjacent to it. This was the model employed by Ofir et al. in 1999 to demonstrate that telomeric sequences influence the activation of nearby replication origins, delaying the synchronization of replication at mid-S phase. The latter suggests that if human telomere repeats silence genes adjacent to repaired ends, then it is also conceivable that nearby genes may be epigenetically inactivated. On the other hand, Kilburn et al. (2001) found that the presence of a telomere sequence in an APRT gene intron in hamster ovary cells only had a modest effect on its expression. Finally, it was Baur et al. in 2001 who, employing a luciferase reporter, supplied convincing evidence of transcriptional silencing near telomeres in humans. The authors found that on placing the reporter adjacent to telomere repeats, there was 10-times lower expression than when they placed it at non-telomeric sites. However, the authors also found that TPE in humans required a histone deacetylase, because on treating the telomeric clones with trichostatin A (a histone deacetylase inhibitor), luciferase expression was restored. Koering et al. (2002) obtained similar results utilizing the EGFP reporter gene in C33-A cells (undifferentiated cervical carcinoma), reverting the repressor effect on employing trichostatin $A$, and they suggested that the position effect depends on the organization of telomeric chromatin, due to that they encountered the release of heterochromatin proteins HP1 $\alpha$ and HP1 $\beta$. Pedram et al. (2006) developed embryonic stem cell clones of mouse with unique-copy gene markers and found that telomeric transgenes were not silenced in cells obtained from 3-day-old embryos as a result of their demethylation during early development, which led the authors to suggest that TPE also plays a role in embryo development. On the other hand, Wright and Shay (1992) also propose that progressive changes in presenescent cells can be the result of the reorganization of telomere chromatin and of the corresponding silencing or desilencing of subtelomere genes. This hypothesis has been extended to include the possibility that silenced proteins can be released from telomeres when the latter are shortened, in order to affect the expression of genes at internal non-telomere sites (Wood and Sinclair, 2002). This idea was based on studies with S. cerevisiae, in which it was demonstrated that gene markers inserted $<4 \mathrm{~kb}$ from telomere repeats are frequently repressed and replicated at the end of the $S$ phase (Dubrana et al., 2001). Although the loss of TPE is not the senescence trigger, it can be responsible for progressive changes in gene expression as a function of replicative age (Wood and Sinclair, 2002).

\section{Role of telomere length in subtelomeric gene expression and its possible relation to cellular senescence}

To date, there is only one report to our knowledge that studies in vivo TPE in human subtelomere genes. The results obtained suggest that the expression of these genes can be influenced by alterations in local heterochromatin structure so that this obstructs access to transcriptional factors (Ning et al., 2003). Due to the fact that few evidence exist about of 
how age-related telomere length affects the expression of specific human subtelomeric genes, we analyzed the relationship between telomere length and gene expression levels in fibroblasts derived from human donors at ages ranging from 0-70 years. We studied three groups of genes localized 100-150 kb, 200-250 kb, and $>300 \mathrm{~kb}$ away from telomeres. We found that chromatin modifier-encoding genes Eu-HMTase1, ZMYND11, and RASA3 were over expressed in adults and implicated in chromatin restructuring (Hernández-Caballero et al., 2009). These genes are interesting because can participate in cellular senescence through the p53-p21Cip1 pathway and can also participate in chromatin restructuring, interacting with remodeling factors including ATP-dependent helicases, histone deacetylases, and histone methyltransferases (Velasco et al., 2006; Zhang et al., 2007). On the other hand, EuHMTase1 can regulate H3-K9 mono- and dimethylation in euchromatin (Tachibana et al., 2005).

\section{Conclusions}

Undoubtedly the Antagonistic pleiotropy helped to understand the seemingly contradictory functions of the cellular senescence, nevertheless still it is not clear how does the senescence response balance tumour suppression, tissue regeneration and ageing phenotypes, for which it will be needed of a major number of studies.

Our results suggest that the expression of the subtelomeric genes modifies with the age, probably as result of decrease of the telomere length. How the changes on telomere length affected the expression of subtelomeric genes? Recently Martínez et al (2010) demonstrated that the RAP1 protein associated with the telomere, also it associates to the subtelomeric genes. Probably this protein might be involved in TPE.

The Senescence is a complex phenomenon where different factors are involved, the changes in expression of subtelomeric genes, as result of the age, is another variable that will help to the understanding cellular senescence.

\section{Acknowledgment}

The authors are grateful to Dra. Martha Ruíz and Maggie Brunner for the support in the preparation of the manuscript. This work was supported by grant Salud-2009-C01-115296, from Consejo Nacional de Ciencia y Tecnología (CONACyT, Mexico).

\section{References}

Bader, N., Jung, T. \& Grune, T. (2007). The proteasome and its role in nuclear protein maintenance. Exp Gerontol, Vol.42, No.9, pp. 864-870, ISSN 1873-6815

Baur, JA., Zou, Y., Shay, JW. \& Wright, WE. (2001). Telomere position effect in human cells. Science, Vol.292, No.5524, pp. 2075-2077, ISSN 1095-9203

Bayne, RA., Broccoli, D., Taggart, MH., Thomson, EJ., Farr, CJ. \& Cooke, HJ. (1994). Sandwiching of a gene within $12 \mathrm{~kb}$ of a functional telomere and alpha satellite does not result in silencing. Hum Mol Genet, Vol.3, No.4, pp. 539-546, ISSN 09646906 
Beausejour, CM., Krtolica, A., Galimi, F., Narita, M., Lowe, SW., Yaswen, P. \& Campisi, J. (2003). Reversal of human cellular senescence: roles of the p53 and p16 pathways. EMBO J, Vol. 22, No.16, pp. 4212-4222, ISSN 1460-2075

Ben-Porath, I \& Weinberg, RA. (2005). The signals and pathways activating cellular senescence. Int J Biochem Cell Biol, Vol.37, No.5, (Epub2004 Dec 30), pp. 961-976, ISSN 1878-5875

Bianchi, A., Stansel, RM., Fairall, L., Griffith, JD., Rhodes, D. \& de Lange, T. (1999). TRF1 binds a bipartite telomeric site with extreme spatial flexibility. EMBO J, Vol.18, No.20, pp. 5735-5744, ISSN 1460-2075

Blagosklonny, M. (2011). Cell cycle arrest is not senescence. Aging, Vol.3, No.2, pp. 94-101, ISSN 1945-4589

Blanpain, C., Mohrin, M., Sotiropoulou, PA. \& Passegue, E. (2011). DNA-damage response in tissue-specific and cancer stem cells. Cell Stem Cell, Vol.8, No.1, pp. 16-29, ISSN 1875-9777

Blasco, MA. (2005). Telomeres and human disease: ageing, cancer and beyond. Nat Rev Genet, Vol. 6, No.8, pp. 611-622, ISSN 1471-0064

Boehm, M. \& Salck, F. (2005). A developmental timing microRNA and its target regulate life span in C. elegants. Science, Vol.310, No.5756, pp. 1954-1957, ISSN 0036-8075

Brandl, A., Hartmann, A., Bechmann, V., Graf, B., Nerlich, M. \& Angele, P. (2011). Oxidative Stress Induces Senescence in Chondrocytes. J Orthop Res, Vol.29, No.7, (Epub 2011 Jan 31), pp. 1114-1120, ISSN 1554-527X

Brunk, UT. \& Terman, A. (2002). Lipofuscin: mechanisms of age-related accumulation and influence on cell function. Free Radic Biol Med, Vol.33, No.5, (Sep 1), pp. 611-619, ISSN 1873-4596

Campisi, J. (2000). Cancer, aging and celular senescence. In vivo, Vol.14, No.1, (Jan-Feb), pp. 183-188, ISSN 1791-7549

Campisi, J. (2005). Aging, tumor suppression and cancer: high wire-act! Mech Ageing Dev, Vol.126, No.1, (Jan), pp. 51-58, ISSN 1872-6216

Campisi, J. \& d'Adda di Fagagna, F. (2007). Cellular senescence: when bad things happen to good cells. Nat Rev Mol Cell Biol, Vol. 8, No.9, (Sep), pp. 729-740, ISSN 1471-0080

Campisi, J. (2011). Cellular senescence: Putting the paradoxes in perspective. Curr opin Genet Dev, Vol.21, No.1, (Feb), pp. 107- 112, ISSN 1879-0380

Cech, TR. (2004). Beginning to understand the end of the chromosome. Cell, Vol.116, No.2, (Jan 23), pp. 273-279, ISSN 1097- 4172

Chai, W., Du, Q, Shay, JW. \& Wright, WE. (2006). Human telomeres have different overhang sizes al leading versus lagging strands. Mol Cell, Vol.21, No.3, (Feb 3), pp. 427-435, ISSN 1097-4164

Chang, BD., Xuan, Y., Broude, EV., Zhu, H., Schott, B., Fang, J. \& Roninson, IB. (1999). Role of p53 and p21waf1/cip1 in senescence-like terminal proliferation arrest induced in human tumor cells by chemotherapeutic drugs. Oncogene, Vol.18, No.34, (Aug 28), pp.4808-4818, ISSN 1476-5594

Chang, W., Dynek, JN. \& Smith, S. (2003). TRF1 is degraded by ubiquitina-mediated proteolysis after release from telomeres. Genes Dev, Vol.17, No.11, (Jun 1), pp. 13281333, ISSN 1549-5477 
Chen, L. \& Widom, J. (2004). Molecular basis of transcriptional silencing in budding yeast. Biochem Cell Biol, Vol.82, No.4, (Aug), pp. 413-418, ISSN 1208-6002

Cherdyntseva, NV., Gervas, PA., Litvyakov, NV., Stakcheeva, MN., Ponomaryeva, AA., Dobrodeev, AY., Denisov, EV., Belyavskaya, VA. \& Choinzonov, EL. (2010). Agerelated function of tumor suppressor gene tp53: contribution to cancer risk and progression. Exp Oncol, Vol.32, No.3, (Sep), pp. 205-208, ISSN 1812-9269

Chiu, CP., Dragowska, W., Kim, NW., Vaziri, H., Yui, J., Thomas, TE., Harley, CB. \& Lansdorp, PM. (1996). Differential expression of telomerase activity in hematopoietic progenitors from adult human bone marrow. Stem Cells, Vol.14, No.2, pp. 239-248, ISSN 0250-6793

Cong, Y., Wright, WE. \& Shay, JW. (2002). Human telomerase and its regulation. Microb Mol Biol Rev, Vol.66, No.3, pp. 407- 425, ISSN 1098-5557

Crabbe, L., Verdun, RE., Haggblom, CI. \& Karlseder, J. (2004). Defective telomere lagging strand synthesis in cells lacking WRN helicase activity. Science, Vol.306, No.5703, (Dec 10), pp. 1951-1953, ISSN 1095-9203

Cryderman, DE., Morris, EJ., Biessmann, H., Elgin, S. \& Wallrath, LL. (1999). Silencing at Drosophila telomeres: Nuclear organization and chromatin structure play critical roles. EMBO J, Vol.18, No.13, (Jul 1), pp. 3724-3735, ISSN 1460- 2075

d'Adda di Fagagna, F., Teo, S. \& Jackson, SP. (2004). Functional links between telomeres and proteins of the DNA-damage response. Genes Dev, Vol.18, No.15, (Aug 1), pp. 17811799, ISSN 1549-5477

d'Adda di Fagagna, F. (2008). Living on a break: cellular senescence as a DNA-damage response. Nat Rev Cancer, Vol.8, No.7, pp. 512-522, ISSN 1474-1768

de Lange, T. (2002). Protection of mammalian telomeres. Oncogene, Vol.21, No.4, (Jan 21), pp. 532-540, ISSN 1476-5594

De, S. (2011). Somatic mosaicism in healthy human tissues. Trends Genet Vol.27, No. 6, pp. 217-223, ISSN 1476-5594

Dimri, GP., Lee, X., Basile, G., Acosta, M., Scott, G., Roskelley, C., Medrano, EE., Linskens, M., Rubelj, I., Pereira-Smith, O., Peacocke, M. \& Campisi, J. (1995). A biomarker that identifies senescent human cells in culture and in aging skin in vivo. Proc Natl Acad Sci USA, Vol.92, No.20, (Sep 26), pp. 9363-9367, ISSN 1091-6490

Duan, J., Zhang, Z. \& Tong, T. (2005). Irreversible cellular senescence induced by prolonged exposure to $\mathrm{H} 2 \mathrm{O} 2$ involves DNA-damage and- repair genes and telomere shortening. Int J Biochem Cell Biol, Vol.37, No. 7, pp. 1407-1420, ISSN 1878-5875

Dubrana, K., Perrod, S. \& Gasser, SM. (2001). Turning telomeres on and off. Curr Opin Cell Biol, Vol.13, No.3, pp. 281-289, ISSN 1879-0410

Espejel, S., Franco, S., Rodríguez-Perales, S., Bouffler, SD., Cigudosa, JC. \& Blasco, MA. (2002). Mammalian Ku86 mediates chromosomal fusions and apoptosis caused by critically short telomeres. EMBO J, Vol.21, pp. 2207-2219, ISSN 1460-2075

Fairall, L., Chapman, L., Moss, H., de Lange, T. \& Rhodes, D. (2001). Structure of the TRFH dimerization domain of the human telomeric proteins TRF1 and TRF2. Mol Cell, Vol.8, No.2, pp. 351-361, ISSN 1097-4164 
Feltes, BC., de Faria Poloni, J. \& Bonatto, D. (2011). The developmental aging and origins of health and disease hypotheses explained by different protein networks. Biogerontology, Vol.12, No.4, (Epub 2011 Mar 5), pp. 293-308, ISSN 1389- 5729

Freund, A., Orjalo, AV., Desprez, PY. \& Campisi, J. (2010). Inflammatory networks during cellular senescence: causes and consequences. Trends Mol Med, Vol.16, No.5, (Epub 2010 May 3), pp. 238-246, ISSN 1471-499X

Funayama, R. \& Ishikawa, F. (2007). Cellular senescence and chromatin structure. Chromosoma, Vol.116, No.5, (Epub 2007 Jun 20), pp. 431-440, ISSN 1432-0886

Gottschling, DE., Aparicio, OM., Billington, BL. \& Zakian, VA. (1990). Position effect at S. cerevisiae telomeres: Reversible repression of Pol II transcription. Cell, Vol.63, No.4, pp. 751-762, ISSN 1097-4172

Greenberg, SB., Grove, GL. \& Cristofalo, VJ. (1977). Cell size in aging monolayer cultures. In Vitro, Vol.13, No. 5, pp. 297-300, ISSN 0073-5655

Greider, CW. \& Blackburn, EH. (1985). Identification of a specific telomere terminal transferase enzyme with two kinds of primer specificity. Cell, Vol.51, No.6, pp. 405413, ISSN 1097-4172

Greider, CW. (1996). Telomere length regulation. Annu Rev Biochem, Vol.65, pp. 337-365, ISSN 1545-4509

Griffith, JD., Comeau, L., Rosenfield, S., Stansel, RM., Bianchi, A., Moss, H. \& de Lange, T. (1999). Mammalian telomeres end in a large duplex loop. Cell, Vol. 97, No.4, pp. 503-514, ISSN 1097-4172

Guarente, L. (1999). Mutant mice live longer. Nature, Vol.402, No.6759, pp. 243-245, ISNN 1476-4687

Guarente, L. (1999). Diverse and dynamic functions of the Sir silencing complex. Nat Genet, Vol.23, No.3, pp. 281-285, ISSN 1546-1718

Gutteridge, JM. (1984). Age pigments: role of iron and copper salts in the formation of fluorescent lipid complexes. Mech Ageing Dev, Vol.25, No.1-2, pp. 205-214, ISSN $1872-6216$

Halaschek-Wiener, J., Vulto, I., Fornika, D., Collins, J., Connors, JM., Le, ND., Lansdorp, PM. \& Brooks-Wilson, A. (2008). Reduced telomere length variation in healthy oldest old. Mech Ageing Dev, Vol.29, No.11, (Epub 2008 Aug 14), pp. 638-641, ISSN 18726216

Hampel, B., Malisan, F., Niederegger, H., Testi, R. \& Jansen-Durr, P. (2004). Differential regulation of apoptotic cell death in senescent human cells. Exp Gerontol, Vol.39, No.11-12, pp. 1713-1721, ISSN 1873-6815

Harley, CB., Futcher, AB. \& Greider, CW. (1990). Telomeres shorten during ageing of human fibroblasts. Nature, Vol.345, No.6274, pp. 458-460, ISSN 1476-4687

Harrington, L., McPhhail, T., Mar, V., Zhou, W., Oulton, R., Bass, MB., Arruda, I. \& Robinson, M. (1997). A mammalian telomerase-associated protein. Science, Vol.275, No.5302, pp. 973-977, ISSN 1095-9203

Hayflick, L. \& Moorhead, PS. (1961). The serial cultivation of human diploid cell strains. Exp Cell Res 1961; Vol.25, pp. 585- 621, ISSN 1090-2422

Hayflick, L. (1998). A brief history of the mortality and immortality of cultured cells. Keio J Med, Vol.47, No.3, pp. 174-182, ISSN 1880-1293 
Hayflick, L. (2003). Living for ever and dying in the attempt. Exp Gerontol, Vol.38, No.11-12, pp. 1231-1241, ISSN 1873-6815

Henikoff, S. (1990). Position-effect variegation after 60 years. Trends Genet, Vol.6, No.12, pp. 422-426, ISSN 0168-9525

Herbig, U., Jobling, WA., Chen, BP., Chen, DJ. \& Sedivy, JM. (2004). Telomere shortening triggers senescence of human cells through a pathway involving ATM, p53, and p21(CIP1), but not p16(INK4a). Mol Cell, Vol.14, No.4, pp. 501-513, ISSN 1097-4164

Hernández-Caballero, E., Herrera-González, NE., Salamanca-Gómez, F. \& Arenas-Aranda, DJ. (2009). Role of telomere length in subtelomeric gene expression and its possible relation to cellular senescence. BMB Rep, Vol.42, No.11, pp. 747- 751, ISSN 1976$670 \mathrm{X}$

Höhn, A., Jung, T., Grimm, S., Catalgol, B., Weber, D. \& Grune, T. (2011). Lipofuscin inhibits the proteasome by binding to surface motifs. Free Radic Biol Med, Vol.50, No.5, (Epub 2010 Dec 16), pp. 585-591, ISSN 1873-4596

Hornsby, PJ. (2011). Cellular aging and cancer. Crit Rev Oncol Hematol, Vol.79, No.2, pp. 189195, ISSN 1040-8428

Hotchkiss, RS., Strasser, A., McDunn, JE. \& Swanson, PE. (2009). Cell death. N Engl J Med, Vol.361, No.16, pp. 1570-1583, ISSN 1533-4406

Houghtaling, BR., Cuttonaro, L., Chang, W. \& Smith, S. (2004). A dynamic molecular link between the telomere length regulator TRF1 and the chromosome end protector TRF2. Current Biology, Vol.14, No.18, pp. 1621-1631, ISSN 1879- 0445

Huang, YC., Hasegawa, H., Wang, SW., Ku, CC., Lin, YC., Chiou, SS., Hou, MF., Wu, DC., Tsai, EM., Saito, S., Yamaguchi, N. \& Yokoyama, KK. (2011). Jun dimerization protein 2 controls senescence and differentiation via regulating histone modification. J Biomed Biotechnol, Epub 2010 Dec 12, ISSN 1110-7251

Hung, YC., Lee, JH., Chen, HM. \& Huang, GS. (2010). Effects of static magnetic fields on the development and aging of Caenorhabditis elegans. J Exp Biol, Vol.213, No.12, pp. 2079-2085, ISSN 1477-9145

Hwang, ES., Yoon, G. \& Kang, HT. (2009). A comparative analysis of the cell biology of senescence and aging. Cell Mol Life Sci, Vol.66, No.15,( Epub 2009 May 7), pp. 25032524, ISSN 1420-9071

Inomata, K., Aoto, T., Binh, NT., Okamoto, N., Tanimura, S., Wakayama, T., Iseki, S., Hara, E., Masunaga, T., Shimizu, H. \& Nishimura, EK. (2009). Genotoxic stress abrogates renewal of melanocyte stem cells by triggering their differentiation. Cell, Vol.137, No.6, pp. 1088-1099, ISSN 1097-4172

Kaminker, PG., Kim, S., Taylor, RD., Zebarjadian, Y., Funk, WD., Morin, GB., Yaswen. P. \& Campisi, J. (2001). TANK2, a new TRF1-associated Poly(ADP-ribose) polymerase, causes rapid induction of cell death upon overexpression. J Biol Chem, Vol.276, No.38, (Epub 2001 Jul 13), pp. 35891-35899, ISSN 1083-351X

Kanoh, J. \& Ishikawa, F. (2003). Composition and conservation of the telomeric complex. Cell Mol Life Sci, Vol.60, No.11, pp. 2295-2302, ISSN 1420-9071

Karlseder, J., Broccoli, D., Day, D., Hardy, S. \& de Lange, T. (1999). p53- and ATMdependent apoptosis induced by telomeres lacking TRF2. Science, Vol.283, No.5406, pp. 1321-1325, ISSN 1095-9203 
Karlseder, J., Smogorzweska, A. \& de Lange, T. (2002). Senescence induced by altered telomere state, not telomere loss. Science, Vol.295, No.5564, pp. 2446-2449, ISSN 1095-9203

Karlseder, J. (2003). Telomere repeat binding factors: Keeping the ends in check. Cancer Letters, vol.194, No.2, pp. 189-197, ISSN 1872-7980

Kavathia, N., Jain, A., Walston, J., Beamer, BA., Fedarko, NS. (2009). Serum markers of apoptosis decrease with age and cancer stage. Aging Vol.1, No.7, pp. 652-663, ISSN 1945-4589

Kilburn, AE., Shea, MJ., Sargent, G. \& Wilson. JH. (2001). Insertion of a telomere repeat sequence into a mammalian gene causes chromosome instability. Mol Cell Biol, Vol.21, No.1, pp. 126-135, ISSN 1097-4164

Kim, NW., Piatyszek, MA., Prowse, KR., Harley, CB., West, MD., Ho, PL., Coviello. GM., Wright, WE., Weinrich, SL. \& Shay, JW. (1994). Specific association of human telomerase activity with immortal cells and cancer. Science, Vol.266, No.5193, pp. 2011-2015, ISSN 1095-9203

Kim, S., Beausejour, C., Davalos, AR., Kaminker, P., Heo, S. \& Campisi, J. (2004). TIN2 mediates functions of TRF2 at Human Telomeres. J Biol Chem, Vol. 279, No.42, (Epub 2004 Aug 3) pp. 43799-43804, ISSN 1083-351X

Kirkwood, TB. (1977). Evolution of ageing. Nature, Vol.170, No.5635, pp. 201-204, ISSN 14764687

Koering, CS., Pollice A., Zibella, MP., Bauwens, S. Puisieux, A., Brunori, M., Brun, C., Martins, L., Sabatier, L., Pulitzer, JF. \& Gilson, E. (2002). Human telomeric position effect is determined by chromosomal context and telomeric chromatin integrity. EMBO Rep, Vol.3, No. 11, pp. 1055-1061, ISSN 1469-221X

König, P. \& Rhodes, D. (1997). Recognition of telomeric DNA. TIBS, Vol.22, No.2, pp. 43-47, ISSN 0968-0004

Kosar, M., Bartkova, J., Hubackova, S., Hodny, Z., Lukas, J. \& Bartek, J. (2011). Senescenceassociated heterochromatin foci are dispensable for cellular senescence, occur in a cell type- and insult-dependent manner and follow expression of p16 (ink4a). Cell Cycle, Vol.10, No.3, pp. 457-468, ISSN 1551-4005

Krishnamurthy, J., Torrice, C., Ramsey, MR., Kovalev, GI., Al-Regaiey, K., Su, L. \& Sharpless, NE. (2004). Ink4a/Arf expression is a biomarker of aging. J Clin Invest, Vol.114, No.9, pp. 1299-1307, ISSN 1558-8238

Lee, BY., Han, JA., Im, JS., Morrone, A., Johung, K., Goodwin, EC., Kleijer, WJ., DiMaio, D. \& Hwang, ES. (2006). Senescence-associated b-galactosidase is lysosomal bgalactosidase. Aging Cell, Vol.5, No.2, pp. 187-195, ISSN 1474-9726

Lee, HW., Blasco, MA., Gottlieb, GJ., Horner, JW., Greider, CW. \& DePinho, RA. (1998). Essential role of mouse telomerase in highly proliferative organs. Nature, Vol.392, No. 6676, pp. 569-574, ISSN 1476-4687

Lei, M., Podell, ER., Baumann, P. \& Cech, TR. (2003). DNA self-recognition in the structure of Pot1 bound to telomeric single-stranded DNA. Nature, Vol.426, No.6963, pp. 198203, ISSN 1476-4687 
Liu, D., O'Connor, M., Qin, J. \& Songyang, Z. (2004). Telosome. A mammalian telomere associated complex formed by multiple telomeric proteins. J Biol Chem, Vol.279, No.49, (Epub 2004 Sep 20), pp. 51338-51342, ISSN 1083-351X

Liu, L., Trimarchi, JR., Smith, PJ. \& Keefe, DL. (2002). Mitochondrial dysfunction leads to telomere attrition and genomic instability. Aging Cell, Vol.1, No.1, pp. 40-46, ISSN 1097-4172

Lowe, SW. \& Sherr, CJ. (2003). Tumor suppression by Ink4a-Arf: progress and puzzles. Curr Opin Genet Dev, Vol.13, No.1, pp. 77-83, ISSN 1879-0380

Machwe, A., Xiao, L. \& Orren, DK. (2004). TRF2 recruits the Werner syndrome (WRN) exonuclease for processing of telomeric DNA. Oncogene, Vol.23, No.1, pp. 149-156, ISSN 1476-5594

Mantell, LL. \& Greider, CW. (1994). Telomerase activity in germline and embryonic cells of Xenopus. EMBO J, Vol.13, No.13, pp. 3211-3217, ISSN 1460-2075

Martínez, P., Thanasoula, M., Caslos, AR., Gómez-López, G., Tejera, AM., Schoefther, S., Dominguez, O., Pisano, DG., Tarsounas, M. \& Blasco, MA. (2010). Mammalian Rap1 controls telomere function and gene expression through binding to telomeric and extratelomeric sites. Nat Cell Biol, Vol.12, No.8, pp. 768-780, ISSN 1097-6256

Martínez, P. \& Blasco MA. (2011). Telomeric and extra-telomeric roles for telomerase and the telomere-binding proteins. Nat Rev Cancer, Vol.11, pp. 161-176, ISSN 1474-175X

Matos, L., Gouveia, A. \& Almeida, H. (2011). Copper ability to induce premature senescence in human fibroblasts. Age (Dordr), Jun 22, ISSN 1574-1587

Mattern, KA., Swiggers, JJ., Nigg, AL., Löwenberg, B., Houtsmuller, AB. \& Zijlmans, JM. (2004). Dynamics of protein binding to telomeres in living cells: Implications for telomere structure and function. Mol Cell Biol, Vol.24, No.12, pp. 5587-5594, ISNN 1098-5549

McClintock, B. (1941). The stability of broken ends of chromosomes in Zea mays. Genetics, Vol.26, No.2, pp. 234-282, ISSN 1943-2631

McEachern, MJ., Krauskopf, A. \& Blackburn, EH. (2000). Telomeres and their control. Annu Rev Genet, Vol. 34, pp. 331-358, ISSN 1545-2948

Michaloglou, C., Vredeveld, LC., Soengas, MS., Denoyelle, C., Kuilman, T., van der Horst, CM., Majoor, DM., Shay, JW., Mooi, WJ. \& Peeper, DS. (2005). BRAFE600associated senescence-like cell cycle arrest of human naevi. Nature, Vol.436, No.7051, pp. 720-724, ISSN 1476-4687

Mitchell, JR., Wood, E. \& Collins, K. (1999). A telomerase component is defective in the human disease dyskeratosis congenita. Nature, Vol.402, No.6761, pp. 551-555, ISSN 1476-4687

Morin, GB. (1989). The human telomere terminal transferase enzyme is a ribonucleoprotein that synthesizes TTAGGG repeats. Cell, Vol.59, No.3, pp. 521-529, ISSN 1097-4172

Narita, M., Nuñez, S., Heard, E., Narita, M., Lin, AW., Hearn, SA., Spector, DL., Hannon, GL. \& Lowe, SW. (2003). Rb- mediated heterochromatin formation and silencing of E2F target genes during cellular senescence. Cell, Vol.113, No.6, pp. 703-716, ISSN 1097-4172

Neidle, S. \& Parkinson, GN. (2003). The structure of telomeric DNA. Curr Opin Struct Biol, Vol.13, No.3, pp. 275-283, ISSN 1879-033X 
Ning, Y., Xu, JF., Li, Y., Chavez, L., Riethman, HC., Lansdorp, PM. \& Weng, NP. (2003). Telomere length and the expression of natural telomeric genes in human fibroblasts. Hum Mol Genet, Vol.12, No.11, pp. 1329-1336, ISSN 1460-2083

Nishio, K., Inoue, A., Qiao, S., Kondo, H. \& Mimura, A. (2001). Senescence and cytoskeleton: overproduction of vimentin induces senescent-like morphology in human fibroblasts. Histochem Cell Biol, Vol.116, No.4, pp. 321-327, ISSN 1432-119X

Nishio, K. \& Inoue, A. (2005) Senescence-associated alterations of cytoskeleton: extraordinary production of vimentin that anchors cytoplasmic p53 in senescent human fibroblasts. Histochem Cell Biol, Vol.123, No.3, pp. 263-273, ISSN 1432-119X

O'Reilly, M., Teichmann, SA. \& Rhodes, D. (1999). Telomerases. Curr Opin Struc Biol, Vol.9, No.1, pp. 56-65, ISSN 1879-033X

Ofir, R., Wong, AC., McDermind, HE., Skorecki, KL. \& Selig, S. (1999). Position effect of human telomeric repeats on replication timing. Proc Natl Acad Sci USA, Vol.96, No.20, pp. 11434-11439, ISSN 1091-6490

Olovnikov, AM. (1996). Telomeres, telomerase and aging: Origin of the Theory. Exp Gerontol, Vol.31, No.4, pp. 443-448, ISSN 1873-6815

Ouellette, MM., Liao, M., Herbert, BS., Johnson, M., Holt, SE., Liss, HS., Shay, JW. \& Wright WE. (2000). Subsenescent telomere lengths in fibroblasts immortalized by limiting amounts of telomerase. J Biol Chem, Vol.275, No.14, pp. 10072-10076, ISSN 00219258

Pedram, M., Sprung, CN., Gao, Q., Lo, AW., Reynolds, GE. \& Murnane JP. (2006). Telomere position effect and silencing of transgenes near telomeres in the mouse. Mol Cell Biol, Vol.26, No.5, pp. 1865-1878, ISSN 1098-5549

Percy, CJ., Power, D. \& Gobe, GC. (2008). Renal ageing: changes in the cellular mechanism of energy metabolism and oxidant handling. Nephrology, Vol.13, No.2, pp. 147-152, ISNN 1440-1797

Pryde, FE. \& Louis, EJ. (1999). Limitations of silencing at native yeast telomeres. EMBO J, Vol.18, No.9, pp. 2538-2550, ISSN 1460-2075

Rai, TS. \& Adams, PD. (2011). Lessons from senescence: Chromatin maintenance in nonproliferating cells. Biochim Biophys Acta. Aug 3, ISSN 0006-3002

Riley, T., Sontag, E., Chen, P. \& Levine, A. (2008). Transcriptional control of human p53regulated genes. Nat Rev Mol Cell Biol, Vol. 9, No.5, pp. 402-412, ISSN 1097-4164

Rochette, PJ. \& Brash, DE. (2008). Progressive apoptosis resistance prior to senescence and control by the anti-apoptotic protein BCL-xL. Mech Ageing Dev, Vol.129, No.4, pp. 207-214, ISSN 1872-6216

Rodier, F. \& Campisi, J. (2011). Four faces of cellular senescence. J Cell Biol, Vol.192, No.4, (Epub 2011 Feb 14), pp. 547-556, ISSN 1540-8140

Saldanha, SN., Andrews, LG. \& Tollefsbol, TO. (2003). Assessment of telomere length and factors that contribute to its stability. Eur J Biochem, Vol.270, No.3, pp. 389-403, ISSN 1432-1033

Salminen, A., Ojala, J. \& Kaarniranta, K. (2011). Apoptosis and aging: increased resistance to apoptosis enhances the aging process. Cell Mol Life Sci, Vol.68, No.6, (Epub 2010 Nov 30), pp. 1021-1031, ISSN 1420-9071 
Schulze, SR., Sinclair, D., Fitzpatrick, KA. \& Honda, BM. (2005). A Genetic and molecular characterization of two Proximal heterochromatic genes on chromosome 3 of Drosophila melanogaster. Genetics, Vol.169, No.4, pp. 2165-2177, ISSN 1943-2631

Serrano, M. \& Blasco, MA. (2001). Putting the stress on senescence. Curr Opin Cell Biol, Vol.13, No.6, pp. 748-753, ISSN 1879-0410

Sherr, CJ. \& DePinho, RA. (2000). Cellular senescence: Mitotic clock or culture shock? Cell, Vol.102, No.4, pp. 407-410, ISSN 1097-4172

Sin, D., Kucia, M. \& Ratajcsak, MZ. (2011). Nuclear and chromatin reorganization during cell senescence and aging- A mini-review. Gerontology, Vol.57, No.1, (Epub 2010 Feb 4), pp. 76-84, ISSN 1423-0003

Smith, S., Giriat, I., Schmitt, A. \& de Lange, T. (1998). Tankyrase, a poly (ADP-ribose) polymerase at human telomeres. Science, Vol.282, No.5393, pp. 1484-1487, ISSN 1095-9203

Smith, S. \& de Lange, T. (2000). Tankyrase promotes telomere elongation in human cells. Curr Biol, Vol.10, No.20, pp. 1299-1302, ISSN 1879-0445

Smogorzewska, A. \& de Lange, T. (2002). Different telomere damage signaling pathways in human and mouse cells. EMBO J, Vol.21, No.16, pp. 4338-4348, ISSN 1460-2075

Smogorzewska, A. \& de Lange, T. (2004). Regulation of telomerase by telomeric proteins. Annu Rev Biochem, Vol.73, pp. 177-208, ISSN 0066-4154

Sprung, CN., Sabatier, L. \& Murnane, JP. (1996). Effect of telomere length on telomeric gene expression. Nucleic Acids Res, Vol.24, No.21, pp. 4336-4340, ISSN 1362-4962

Stellwagen, AE., Haimberger, ZW., Veatch, JR. \& Gottschling, DE. (2003). Ku interacts with telomerase RNA to promote telomere addition at native and broken chromosome ends. Genes Dev, Vol.17, No.19, (Epub 2003 Sep 15), pp. 2384-2395, ISSN 1549-5477

Stewart, SA., Ben-Porath, I., Carey, VJ., O'Connor, BF., Hahn, WC. \& Weinberg, RA. (2003). Erosion of the telomeric single-strand overhang at replicative senescence. Nat Genet, Vol.33, No.4, (Epub 2003 Mar 24), pp. 492-496, ISSN 1546-1718

Su, X., Paris, M., Gi, YJ., Tsai, KY., Cho, MS., Lin, YL., Biernaskie, JA., Sinha, S., Prives, C., Pevny, LH., Miller. FD. \& Flores ER. (2009). TAp63 prevents premature aging by promoting adult stem cell maintenance. Cell Stem Cell, Vol.5, No.1, pp. 64-75, ISSN 1875-9777

Tachibana, M., Ueda, J., Fukuda, M., Takeda, N., Ohta, T., Iwanari, H., Sakihama, T., Kodama, T., Hamakubo, T. \& Shinkai, Y. (2005). Histone methyltransferases G9a and GLP form heteromeric complexes and are both crucial for methylation of euchromatin at H3-K9. Genes \& Dev. Vol.19, No.7, pp. 815-826, ISSN 1549-5477

Thacker, J. \& Zdzienicka, MZ. (2004). The XRCC genes: expanding roles in DNA doublestrand break repair. DNA Repair, Vol.3, No. 8-9, pp. 1081-1090, ISNN 1568-7856

Thomas, E., al-Baker, E., Dropcova, S., Denyer, S., Ostad, N., Lloyd, A., Kill, IR. \& Faragher, RG. (1997). Different kinetics of senescence in human fibroblasts and peritoneal mesothelial cells. Exp Cell Res, Vol.236, No.1, pp. 355-358, ISSN 1090-2422

Tuminello ER \& Han SD. (2011). The apolipoprotein e antagonistic pleiotropy hypothesis: review and recommendations. Int J Alzheimers Dis, Vol.24, pp. 1-12, ISSN 2090-0252

Van Steensel, B., Smogorzewska, A. \& de Lange, T. (1998). TRF2 protects human telomeres from end-to-end fusions. Cell, Vol.92, No.3, pp. 401-413, ISSN 1097-4172 
Vavrova, J. \& Rezacova, M. (2011). The importance of senescence in ionizing radiationinduced tumour suppression. Folia Biologica, Vol.57, No.2, pp. 41-46, ISSN 00155500

Velasco, G., Grkovic, S. \& Ansieau, S. (2006). New insights into BS69 functions. J Biol Chem, Vol.281, No.24, (Epub 2006 Mar 24), pp. 16546-16550, ISSN 1083-351X

von Zglinicki, T. (2002). Oxidative stress shortens telomeres. Trends Biochem Sci, Vol.27, No.7, pp.339-344, ISSN 0968-0004

Vousden, KH. \& Lu, L. (2002). Live or let die: the cell's response to p53. Nat Rev Cancer, Vol.2, No.8, pp. 594-604, ISSN 1474-1768

Wakimoto, BT. (1998). Beyond the nucleosome: Epigenetic aspects of position-effect variegation in Drosophila. Cell, Vol.93, No.3, pp. 321-324, ISSN 1097-4172

Walker, RF. (2011). Developmental theory of aging revisited: focus on causal and mechanistic links between development and senescence. Rejuvenation Res, Vol.14, No.4, (Epub 2011 Jul 18), pp. 429-36, ISSN 1557-8577

Wang, E. \& Gundersen, D. (1984). Increased organization of cytoskeleton accompanying the aging of human fibroblasts in vitro. Exp Cell Res, Vol.154, No.1, pp. 191-202, ISSN 1090-2422

Williams, G. (1957). Pleiotropy, natural selection, and the evolution of senescence. Evolution, Vol.11, pp. 398-411, ISSN 1558-5646

Wood, JG. \& Sinclair, DA. (2002). TPE or not TPE? It's no longer a question. TRENDS Pharmacol Sci, Vol.23, No.1, pp. 1-4, ISSN 1873-3735

Wright, WE. \& Shay, JW. (1992). Telomere positional effects and the regulation of cellular senescence. Trends Genet, Vol.8, No.6, pp. 193-197, ISSN 0168-9525

Wright, WE., Piatyszek, MA., Rainey, WE., Byrd, W. \& Shay, JW. (1996). Telomerase activity in human germline and embryonic tissues and cells. Dev Genet, Vol.18, No.2, pp. 173-179, ISSN 0192-253X

Wright, WE. \& Shay, JW. (2005). Telomere-binding factors and general DNA repair. Nat Genet, Vol.37, No.2, pp. 116-118, ISSN 1546-1718

Xin, H., Liu, D. \& Songyang, Z. (2008). The telosome/shelterin complex and its functions. Genome Biol, Vol.9, No.9, (Epub 2008 Sep 18), pp. 232-236, ISSN 1465-6914

Yan, Q., Zheng, Y. \& Harris. CC. (2005). POT1 and TRF2 cooperate to maintain telomeric integrity. Mol Cell Biol, Vol.25, No.3, pp. 1070-1080, ISSN 1098-5549

Yanaka, M., Honma, T., Sato, K., Shinohara, N., Ito, J., Tanaka, Y., Tsuduki, T. \& Ikeda, I. (2011). Increased monocytic adhesion by senescence in human umbilical vein endothelial cells. Biosci Biotechnol Biochem, Vol.75, No.6, (Epub 2011 Jun 13), pp. 1098-1103, ISSN 1347-6947

Ye, JZ. \& de Lange, T. (2004). TIN2 is a tankyrase 1 PARP modulator in the TRF1 telomere length control complex. Nat Genet, Vol.36, No.6, pp. 618-623, ISSN 1546-1718

Zahn, JT., Louban, I., Jungbauer, S., Bissinger, M., Kaufmann, D., Kemkemer, R. \& Spatz, JP. (2011). Age-dependent changes in microscale stiffness and mechanoresponses of cells. Small, Vol.7, No.10, (Epub 2011 May 2), pp. 1480-1487, ISSN 1613-6829

Zhang, W., Chan, HM., Gao, Y., Poon, R. \& Wu, Z. (2007). BS69 is involved in cellular senescence through the p53-p21Cip1 pathway. EMBO Rep, Vol.8, No.10, (Epub 2007 Aug 24), pp.952-958, ISSN 1469-3178 
Zhou, XZ. \& Lu, KP. (2001). The PIN2/TRF1 interacting protein PinX1 is a potent telomerase inhibitor. Cell, Vol.107, No.3, pp. 347-359, ISSN 1097-4172 


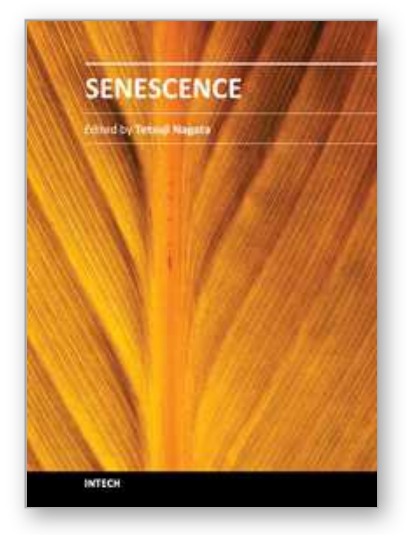

\author{
Senescence \\ Edited by Dr. Tetsuji Nagata
}

ISBN 978-953-51-0144-4

Hard cover, 850 pages

Publisher InTech

Published online 29, February, 2012

Published in print edition February, 2012

The book "Senescence" is aimed to describe all the phenomena related to aging and senescence of all forms of life on Earth, i.e. plants, animals and the human beings. The book contains 36 carefully reviewed chapters written by different authors, aiming to describe the aging and senescent changes of living creatures, i.e. plants and animals.

\title{
How to reference
}

In order to correctly reference this scholarly work, feel free to copy and paste the following:

Diego Julio Arenas-Aranda, Elena Hernández-Caballero and Fabio Salamanca-Gómez (2012). Cellular Senescence and Its Relation with Telomere, Senescence, Dr. Tetsuji Nagata (Ed.), ISBN: 978-953-51-0144-4, InTech, Available from: http://www.intechopen.com/books/senescence/cellular-senescence-and-its-relationwith-telomere-

\section{INTECH}

open science | open minds

\author{
InTech Europe \\ University Campus STeP Ri \\ Slavka Krautzeka 83/A \\ 51000 Rijeka, Croatia \\ Phone: +385 (51) 770447 \\ Fax: +385 (51) 686166 \\ www.intechopen.com
}

\author{
InTech China \\ Unit 405, Office Block, Hotel Equatorial Shanghai \\ No.65, Yan An Road (West), Shanghai, 200040, China \\ 中国上海市延安西路65号上海国际贵都大饭店办公楼405单元 \\ Phone: +86-21-62489820 \\ Fax: $+86-21-62489821$
}


(C) 2012 The Author(s). Licensee IntechOpen. This is an open access article distributed under the terms of the Creative Commons Attribution 3.0 License, which permits unrestricted use, distribution, and reproduction in any medium, provided the original work is properly cited. 